\title{
Empowering Students Through Project- Based Learning: Perceptions Of Instructors And Students In Vocational Education Institutes In Thailand
}

\author{
Anuvat Tongsakul, King Mongkut's University of Technology Thonburi, Thailand \\ Kalayanee Jitgarun, King Mongkut's University of Technology Thonburi, Thailand \\ Weerachai Chaokumnerd, Office of the National Broadcasting and Telecommunications Commission, Thailand
}

\begin{abstract}
The purpose of this study was to identify and compare instructors' and students' perceptions of factors that contribute to the effective use of Project-Based Learning (PBL) in Thailand. The sample for the study consisted of 247 electrical technology instructors from Thai vocational education institutes and 161 students who were electrical power graduates from these institutes. The data was analyzed using factor analysis and structural equation modeling with LISREL ${ }^{T M}$. The results of the study indicated that both instructors and students agreed on the importance of two factors: Motivation to Learn and use of the Scientific Process. Students were significantly more likely to value Sharing Ideas and Thinking Skills. The role of instructors and students in the $P B L$ classroom is discussed.
\end{abstract}

Keywords: Empowering; Project-Based Learning; Vocational Education

\section{INTRODUCTION}

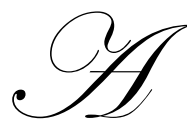

$\mathrm{s}$ a result of Thailand's Education Act (Office of the National Education Commission, 2003), the Thai educational system has been scrutinized and reformed rigorously. Students' thinking and problem-solving skills, particularly in areas of scientific studies, have been two of the targets of scrutiny and reform. The Act mandated that, in organizing the learning process, the educational institutions and agencies concerned should focus more on thinking processes, knowledge application, and problem solving. The Act also encouraged "learning activities that drew on authentic experience, practical work, and critical thinking" (Office of the National Education Commission 2003, Section 24).

Reform has aimed to move away from teacher-centered learning and memorization in order to:

A. promote thinking and analyzing on the part of students themselves;

B. encourage students to learn from their experience and practice; and

C. engage in problem-based learning (Education for all, 2000).

As a vehicle for achieving these goals, Project-Based Learning (PBL) is a preferred pedagogy in that it allows learners to share their ideas so they can brainstorm and solve problems together while the instructor supervises, guides, and assists learners until they can create a meaningful and useful project by themselves (Markham et al., 2003). For students' independence, PBL offers learners opportunities to study, search data, set goals, plan, design, implement, try out, make a presentation on a report, and evaluate their own learning according to their interests and aptitudes (Mulkam \& Mulkam, 2002; Office of the National Primary Education Commission, 2002). Furthermore, PBL enhances learners' capabilities to construct a body of knowledge (Kaewdang, 1998). For these reasons, PBL is a relevant approach in the Thai context. PBL is not the only approach that might be used in 
teaching and learning at the vocational level. However, it is particularly relevant in a vocational education context. Universities and vocational institutes require different approaches, the latter being oriented towards practice and providing students with representations of working life (Vesterinen \& Lasonen, 2000). PBL allows for the integration of theory and practice so important in vocational education (Poell, Van der Krogt \& Warmerdam, 1998).

The review of the literature conducted for this study uncovered no existing studies related to PBL in vocational education in Thailand. This is despite the fact that the success of Thailand's educational reform at the vocational level will be dependent on empowering students to think and learn in accord with their potential as stated in the National Education Act (1999) and Amendments (Office of the National Education Commission, 2003).

\section{PURPOSE AND RESEARCH QUESTIONS}

The specific purpose of the study reported on in this paper was to examine the differences between Thai electrical technology instructors' and students' perceptions of the factors that empower vocational education students through PBL in Thailand. The innovative nature of PBL within the context of Thai vocational education means that the issues of how both instructors and students perceive the value of this pedagogy is critical and has implications for the acceptance and use of this pedagogy by others in Thailand.

To this end, three research questions were formulated;

1. What are Thai instructors' perceptions of the factors that empower students in PBL?

2. What are Thai students' perceptions of the factors that empower students in PBL?

3. How do Thai instructors' perceptions differ from students' with regard to the factors that empower students?

\section{PROJECT-BASED LEARNING (PBL)}

The "project" has been part of educational practice since the 16th century. PBL first appeared in the late Renaissance in the architecture schools of Italy (1590-1765). The approach, which initially focused on the technological aspects of building machines, eventually incorporated scientific knowledge and became prominent as part of the syllabus of engineering schools in the United States (see Pannabecker, 1995). From1880 to 1915, projects were integrated into public schools in America as part of the manual training movement. John Dewey and his group advocated projects as a means of learning by doing based on student self-interest and a constructivist approach (Fallik et al., 2008).

Knoll (1997) cites Dewey, who describes the project method as problem-solving which challenges and builds constructive skills. Purposeful action is central to the method. In Kilpatrick's (1918) view, projects had four phases: purposing, planning, executing, and judging. The ideal progression was when all four phases were initiated and completed by the pupils and not by the teacher.

Yoon (2001) found that, in PBL, it is particularly important to teach students to regulate their own pace of learning and to act independently. Central, therefore, to the success of PBL in vocational education is the empowerment of students so that they can be independent, responsible for their own learning, set goals, pose questions, and be motivated to learn on their own. Blumenfeld et al. (1991) also found that the success of PBL was dependent on how interesting and worthwhile the students found the activity to be. This is why PBL has an important role to play in helping students explore important and meaningful questions, investigate solutions to a problem, and develop a deep, integrated understanding of content and process (Frank, Lavy \& Elata, 2003).

Orevi and Danon (1999) noted the advantages of PBL from the students' point of view, which are that it develops data collection and presentation skills, thinking skills, suits personal learning styles, enhances motivation, and develops independent learners. Learners explore important and meaningful questions through a process of investigation by asking questions, making predictions, designing investigations, collecting and analyzing the data, using technology, and making products. Through collaboration, students work together to solve problems as well as share ideas to find answers to questions (Krajcik et al., 1999). In the PBL environment, students build their own 
knowledge by active learning, interacting with the environment, working independently or collaborating in teams, while the teacher directs and guides (Thomas, 2000).

\section{METHODS}

\section{Sample}

There were two groups of participants in this study: 247 instructors and 161 students. Instructors were recruited from 188 vocational education institutes (post-secondary vocational schools) in the northern, northeastern, central, and southern regions of Thailand. Of these $161,92 \%$ were male and $70 \%$ held a bachelor's degree in electrical power. Instructors ranged in age from 24 years to 59 years. The greatest proportion or $43.72 \%$ ( $\mathrm{n}=108$ ) were in the $25-35$ years age bracket, $3.24 \%(n=8)$ were younger than 25 years, 30.77\% $(n=76)$ were in the $36-45$ years and $22.27 \%(n=55)$ were older than 45 years.

The students were graduates of vocational education institutes from the same four regions of Thailand as the instructor participants. They all held a diploma in electrical power. In Thailand, approximately 53\% of diploma students go directly to work and the remainders move to the university to do further study in the degree program (Bureau of Monitoring and Evaluation of Vocational Education, 2009). At the time of participation in the study, some of these students were attending their third and fourth year in one of the four Thai universities that offer a bachelor's degree in industrial education technology. Students who graduate from vocational education institutes in the field of electrical technology can further their higher education at any one of four universities. These universities offer programs in major fields in technical education. The researchers chose to draw the sample of students from the university which offered a major in electrical technology education. This university (King Mongut's University of Technology Thonburi, Thailand) is the one with the largest concentration of electrical power graduates. This university was also where one of the researchers was working and where another of the authors was a $\mathrm{PhD}$ candidate. It was beyond the scope of this study to sample a larger number of universities.

Sixty-one per cent of the participating students were majoring in electrical power and $86 \%$ were males. All student participants were between $20-24$ years of age, most commonly $96 \%$ between $20-22$ years. The university offered a two-year continuing program for three-year higher vocational education certificate or diploma level as well as a Master's degree level program in industrial education technology in fields such as mechanical technology education, electrical technology education, civil technology education, and production technology education. However, our study was only concerned with a two-year continuing program for three-year higher vocational education certificate or diploma level graduates whose major was in electrical technology education.

The vocational institutes involved offered both a three-year vocational certificate and a diploma level program or a two-year higher vocational education certificate in areas such as: (1) Industrial Trade, including the Mechanical Technology Program, Production Technology Program, Metal Work Program, and Electrical Power Technology Program, to name a few; (2) the Textile Industry, including Textile Technology, Textile Chemistry Program, Garment Industry Program, and Silk-weaving and Folk Textile Program; and (3) Information and Communication Technology which includes programs such as Information Technology Program (Office of the Vocational Education Commission, 2003). The main purpose and function of vocational education institutes are, not only to develop appropriate knowledge, attitude, and skills of vocational education at the basic education level but also to allow an individual to progress to an advanced degree level.

\section{The Context}

For a two-year continuing program degree and three-year higher vocational education certificate or diploma level, the term "project" refers to a small-scale project which usually takes place in the students' final year. In the case of a PBL project in the field of electrical technology, for example, students need to apply appropriate knowledge, skills, and creativity to solve a particular electrical technology problem. An emphasis is placed on discovering solutions to specific human problems, and a topic can come from various sources. These may include a student's special area of interest or other research projects or industries. Generally, students receive the support of an advisor when choosing their topic and an electrical technology specification is formulated (Jitgarun et al. n.d.). 
For a successful project, not only will students work as a team, but they will also have to learn as a team. Students should apply research techniques they have learned from their courses when searching for possible ways of solving the problems. Two examples of PBL senior projects that have been undertaken in the field of electrical technology in the three-year higher vocational education certificate or diploma level course are: "A Bamboo Cutting Machine Using Direct Start and Reverse Control" and "A Motor Coil Winding Machine". In the two-year continuing program degree, two examples of completed projects are: "A Water Heater Induction Heating Technique" and "Dimming Electronic Ballast for Fluorescent Lamps".

\section{Measures}

The study involved the administration of a questionnaire to instructors and students. The questionnaire was developed specifically for the context of the study. The questionnaire contained 72 items. These items were elements of a PBL theoretical framework derived from Jitgarun et al. (2006), Jitgarun, Tongsakul, and Meejaleurn (2008), Jitgarun and Tongsakul (2009), Petcharak (2001). They were also based on the results of participatory observations in a demonstration school at King Mongkut's University of Technology, Thonburi (KMUTT), Thailand. In this demonstration school, students were taught using constructionism and a PBL approach with teachers as facilitators (Jitgarun, Thaweesin, Vithayaporn, Chunkul \& Tongsakul, 2006). According to Jitgarun et al. (2006), "Constructionism is a learning process developed by learners through thinking and doing. Learners must be in a facilitating environment where technology is used as a tool to support learner's progress so that they can apply their knowledge in real life" (p. 3).

For the questionnaire, the word "perceptions" refer to the perceptions or considered judgment of both students and instructors of the elements or components of PBL that would help empower the students to conduct the project successfully. The questionnaire's 72 items were grouped into nine categories (see also Table 1) as follows:

1. $\quad$ Facilitation refers to an instructor's support and guidance for students.

2. Goal-Setting refers to a student's ability to set goals and specify procedures to reach the goal.

3. Motivation to Learn refers to a student's curiosity for learning.

4. Planning refers to a student's choice of efficient and effective approaches to achieve goals and specification of tasks to be completed.

5. Thinking Skills refer to rationality in thoughts and actions, creativity, flexible ideas, vision, resourcefulness, reflections and discovery of new principles or methods.

6. Scientific Process refers to skills and aptitude for science which include systematic methods in knowledge acquisition, developing problem statements, hypothesis testing, data analysis, drawing valid conclusions and understanding the applicability of project results.

7. $\quad$ Sharing Ideas refers to an interaction with peers.

8. Intelligent Awareness refers to a student's ability to learn in such areas as language, numeracy, rationality, dimension, non-verbal expression, music appreciation, perception of external stimulus as well as selfunderstanding through empirical inquiry and interaction with the surrounding environment.

9. Learning by Doing refers to a student creating their own understandings through real-life activities.

Table 1: Summary Of Questionnaire Items Grouped According To Each Factor

\begin{tabular}{|l|c|}
\hline \multicolumn{1}{|c|}{ Factor } & Number of Questions \\
\hline Facilitation & 10 \\
\hline Goal-Setting & 3 \\
\hline Motivation to Learn & 10 \\
\hline Planning & 3 \\
\hline Thinking Skills & 7 \\
\hline Scientific Process & 8 \\
\hline Sharing Ideas & 15 \\
\hline Intelligent Awareness & 9 \\
\hline Learning by Doing & 7 \\
\hline
\end{tabular}


The questionnaire used a seven-point Likert scale (Strongly agree, Agree, Somewhat agree, Neither agree nor disagree, Somewhat disagree, Disagree, Strongly disagree) (Warr et al., 1979) and required approximately 30 minutes to complete. The content validity was verified by five experts, based on Yaghmaie's (2003) method. The content experts consisted of two instructors in electrical engineering, two instructors in vocational education, and one instructor in curriculum and instruction. All of these experts hold doctoral degree or associate professor positions. The experts were separate from the research team. Thirty instructors and 30 students were also invited to test the reliability of the questionnaire. Results of the Cronbach alpha reliability coefficients of the first and the second questionnaires were 0.98 and 0.96 respectively. The index of item-objective congruence (IOC) of each item was $\geq 0.50$ (Turner \& Carlson, 2003). While increasing the value of alpha is partially dependent upon the number of items in the scale, it should be noted that this has diminishing returns. It should also be noted that an alpha of 0.70 is the minimum generally acceptable value (Gliem \& Gliem, 2003; Nunnally, 1988). George and Mallery (2003) provide the following rules of thumb: " $\geq 0.9$ - Excellent, $\geq 0.8$ - Good and $\geq 0.7$-Acceptable" (p. 231).

\section{Procedures}

The study began with the selection of a sample. Recruitment was facilitated by the fact that one of the researchers is an electrical power instructor from a vocational education institute located in the southern part of Thailand. Another works in the Electrical Technology Department of the university from which students were recruited. Another one of the researchers is also a member of the Amateur Radio Committee at Office of the National Broadcasting and Telecommunications Commission, Bangkok, Thailand.

Five hundred questionnaires for instructors were mailed to the vocational institutes together with the document granting permission to conduct the study. Each mailing consisted of a cover letter requesting the vocational education institute director's permission to conduct the study, copies of the questionnaire, and a timeframe reminder requesting the return of the questionnaire. A self-addressed, stamped envelope was also included for return of the completed questionnaire. After the deadline of one month, the researchers contacted by phone the head of the electrical power department at the vocational education institutes to request the return of any completed questionnaires. Forty-nine per cent of those who received the questionnaire completed and returned it.

Student participants were recruited from the 288 students in the Electrical Technology Department, Faculty of Industrial Education, King Mongkut's University of Technology, Thonburi, Thailand. Questionnaires were distributed to all those students who were graduates of electrical power programs at the vocational institutes. Students could return the questionnaire in person to one of the researchers who were teaching in this department. Fifty-six percent of those who received the questionnaire completed and returned it.

\section{Data Analysis}

The adequacy of the returned questionnaires was tested by the Kaiser-Meyer-Olkin (KMO) (Nunnally, 1988) to measure sampling adequacy of both instructors and students, and KMO values were 0.92 and 0.82 respectively. The values of KMO were more than 0.50 but less than 1.00 . The data was first analyzed using descriptive statistics. Next, the Pearson product-moment correlation coefficient of each variable was used to show the relation matrix and to test significance. Significant variables with the factor extraction method by principal component analysis and maximum likelihood estimation were used to test which method could best describe the variance and to determine the best method to extract factors, (that is, Gorsuch, 1983; Harman, 1976).

The variables were analyzed using principal component analysis and factor rotation with orthogonal rotation axis (Varimax). Factors were identified by means of eigenvalues which are higher or equal to 1-0 and have at least three variables describing that factor with each variable having a weight value of more than 0.40 according to Vogt (2007). Interpreting factors and labeling them with new variables required experience in labeling and giving meaningful names to each factor by considering variables for such factors. Those involved in this step were the principal investigator, co-investigator, as well as five experts.

Structural equation modeling using LISREL $^{\mathrm{TM}}$ was relied on for a confirmatory model of instructors' and students' perceptions. LISREL ${ }^{\mathrm{TM}}$ is perceived as the most general method for carrying out confirmatory factor 
analysis (CFA) and the causal relationships among latent variables (Vogt, 2007; Wen et al., 2004). Thus, the factors of instructors' and students' perceptions that would empower students to conduct the project successfully were analyzed and confirmed by structural equation modeling using LISREL $^{\mathrm{TM}}$.

\section{RESULTS}

\section{Analysis Of Instructors' Perceptions}

Factor analysis of instructors' perceptions revealed that nine factors empowered students through PBL. These were: 1) Motivation to Learn; 2) Planning; 3) Thinking Skills; 4) Sharing Ideas; 5) Facilitation; 6) Learning by Doing; 7) Scientific Process; 8) Intelligent Awareness; and 9) Goal-Setting. The results could explain $72.17 \%$ of the total variance. The results of the first-order correlation coefficients between nine factors and 72 variables (see Table 1) were 0.42-0.81. For the second-order correlation coefficients between the nine factors and PBL, the results were $0.45-0.80$, which were at a high level as shown in Figure 1. The correlation coefficients within the nine internal factors were 0.01-0.09, which were at a low level. It can be concluded that these nine factors affected the empowerment of students as perceived by instructors.

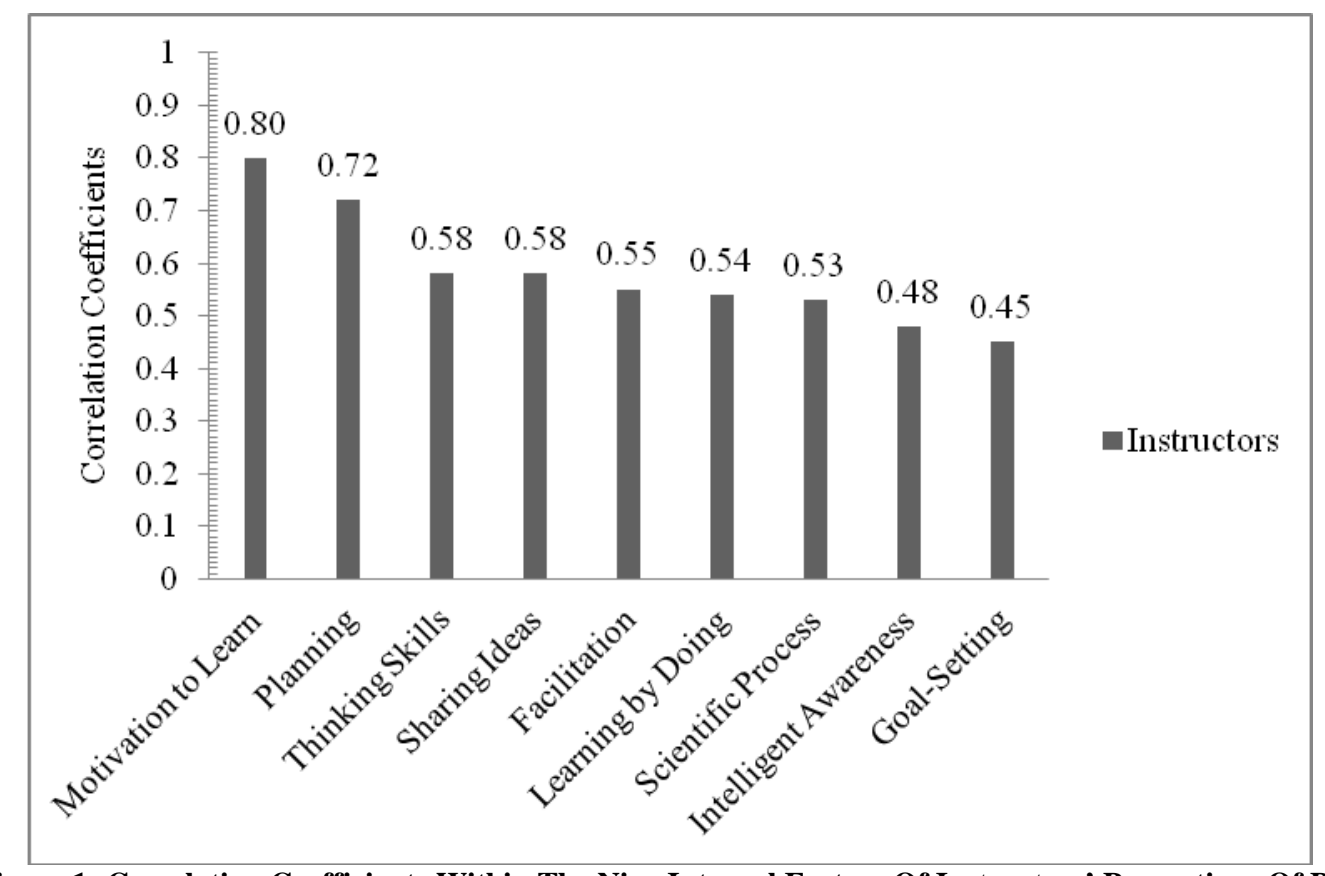

Figure 1: Correlation Coefficients Within The Nine Internal Factors Of Instructors' Perceptions Of PBL

To confirm those nine factors already developed through factor analysis, a model modification was developed from indices using the method of Joreskog and Sorbom (1996). A model of measurement of second-order factor analysis of instructors' perceptions had a high satisfactory validity and fit of the empirical data. The statistical values were as follows: $\chi^{2}$ non significant, $\mathrm{p}=1.00$, RMSEA $=0.00, \mathrm{ECVI}=4.78$, Model $\mathrm{AIC}=727.47, \mathrm{NFI}=$ $0.99, \mathrm{CFI}=1.00, \mathrm{SRMR}=0.04, \mathrm{GFI}=0.96$ and $\mathrm{AGFI}=0.91$. Thus, the fit indices were good which implies that the component model developed by the researchers was in accordance with the empirical data at a high level. The second- order factor analysis had factor loadings weighted 0.81-0.96. When the factors were ranked in terms of importance as perceived by instructors, the order was as follows: Thinking Skills (0.96), Intelligent Awareness (0.93), Sharing Ideas (0.85), Motivation to Learn (0.81), and Scientific Process (0.81). The results of the factor analysis and LISREL ${ }^{\mathrm{TM}}$ analysis were then compared as shown in Table 2. 
Table 2: Comparison Of The Results Of The Factor Analysis And LISREL ${ }^{\text {TM }}$ Analysis Of Instructors' Perceptions

\begin{tabular}{|l|c|c|}
\hline \multicolumn{1}{|c|}{ Factor } & Factor Analysis & LISREL $^{\text {TM }}$ Analysis $^{-1}$ \\
\hline Motivation to Learn & 0.80 & -81 \\
\hline Planning & 0.72 & 0.85 \\
\hline Sharing Ideas & 0.58 & 0.96 \\
\hline Thinking Skills & 0.58 & - \\
\hline Facilitation & 0.55 & - \\
\hline Learning by Doing & 0.54 & 0.81 \\
\hline Scientific Process & 0.53 & 0.93 \\
\hline Intelligent Awareness & 0.48 & - \\
\hline Goal-Setting & 0.45 & \\
\hline
\end{tabular}

Table 2 revealed that nine factors resulted from the factor analysis. However, using a LISREL ${ }^{\mathrm{TM}}$ analysis to confirm those nine factors, it was found that only five factors of instructors' perceptions related to the effective use of PBL.

\section{Descriptive Summary Of Instructors' Perceptions}

The most important factor for empowering learners through PBL identified by instructors was that of Thinking Skills. Instructors noted that learners need skills in complex higher-order thinking, creative thinking, and critical thinking. They also need an ability to control their emotion and feelings. The second most important factor for empowering learners through PBL identified by instructors was Intelligent Awareness. The variables identified as important included the need for learners to know and adapt themselves based on their understanding. They also need an ability to interact with nature and the environment, to appreciate music, to know, perceive and distinguish emotions. The students' ability to do projects is partly dependent on their awareness of concepts of electrical sciences which deal with natural phenomena. In order to fully understand and apply projects in the field of electrical power, it is necessary for students to interact with natural phenomena. For their projects to be successful, students require an ability to integrate their knowledge of electricity with the demands of their surroundings. It is this ability that the questionnaire attempted to measure. Instructors also identified that it is important for learners to learn how to learn.

The third most important factor for empowering learners through PBL identified by instructors was that of Sharing Ideas. Learners need a capacity to reflect on their ideas. They need to use their different talents to help one another and share ideas collaboratively so others have access to new ideas. The fourth most important factor for empowering learners through PBL identified by instructors was Motivation to Learn. It includes curiosity, determination an ability to keep up with and adapt to changing situations, and persevere in the face of obstacles or problems. The last important factor for empowering learners through PBL identified by instructors was Scientific Process. Learners need an ability to state the problem, choose the best way to solve problems, analyze data, test hypotheses, and use scientific methods.

\section{Analysis Of Students' Perceptions}

Factor analysis of students' perceptions revealed that eight factors empowered students through PBL. These were: 1) Motivation to Learn; 2) Planning; 3) Thinking Skills; 4) Goal-Setting; 5) Intelligent Awareness; 6) Scientific Process; 7) Facilitation; and 8) Sharing Ideas. The results could explain $64.46 \%$ of the total variance. A study of the correlation coefficients indicated between eight and 37 variables (see Table 1) were from 0.41-0.79 and the correlation coefficients between eight factors were between 0.49-0.86 which were at a high level as shown in Figure 2. The correlation coefficients within the eight internal factors ranged from $0.02-0.09$, which were at a low level. It can be concluded that these eight factors affected student perceptions of PBL. 


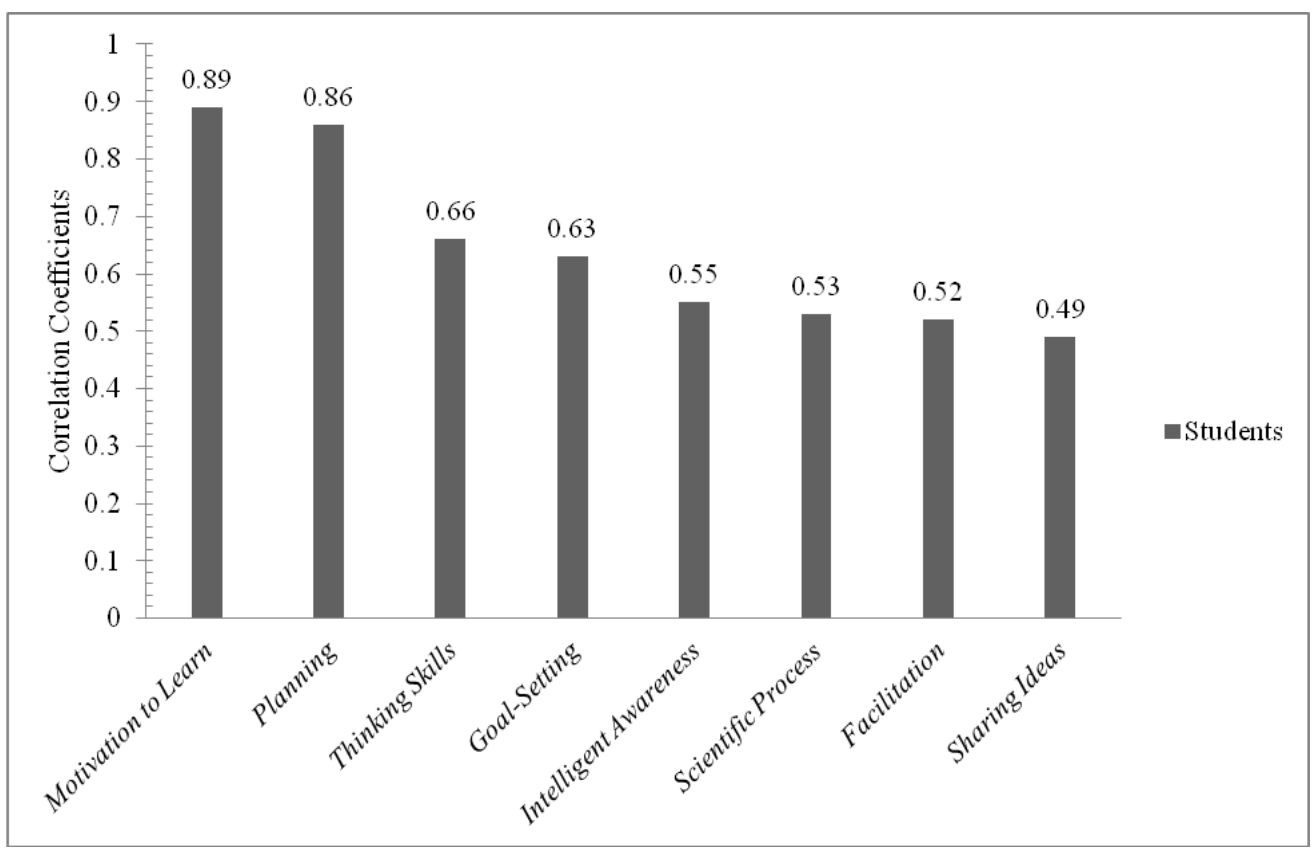

Figure 2: Correlation Coefficients Within The Eight Internal Factors Of Students' Perceptions Of PBL

To confirm those eight factors already developed through factor analysis, a model of modification indices was developed using the method of Joreskog and Sorbom (1996). A model of measurement of second-order factor analysis had a high satisfactory validity and fit the empirical data. The statistical values were as follows: $\chi^{2}$ non significant, $\mathrm{p}=1.00, \mathrm{RMSEA}=0.00, \mathrm{ECVI}=2.90$, Model $\mathrm{AIC}=270.56, \mathrm{NFI}=0.98, \mathrm{CFI}=1.00, \mathrm{SRMR}=0.04$, GFI $=0.95$ and AGFI $=0.91$. Thus, the fit indices were good. The second-order factor analysis had factor loadings weighted 0.81-0.96. When the factors were ranked in terms of importance as perceived by students, the order was as follows: Motivation to Learn (0.92); Thinking Skills (0.85); Scientific Process (0.82); Sharing Ideas (0.81); and Goal-Setting (0.77). The results of the factor analysis and LISREL ${ }^{\mathrm{TM}}$ analysis of students' perceptions were then compared as shown in Table 3.

Table 3: Comparison Of The Results Of Factor Analysis And LISREL ${ }^{\text {TM }}$ Analysis Of Students' Perceptions

\begin{tabular}{|l|c|c|}
\hline \multicolumn{1}{|c|}{ Factor } & Factor Analysis & LISREL $^{\text {TM }}$ Analysis $^{-1}$ \\
\hline Motivation to Learn & 0.89 & - \\
\hline Planning & 0.86 & 0.85 \\
\hline Thinking Skills & 0.66 & 0.77 \\
\hline Goal-Setting & 0.63 & - \\
\hline Intelligent Awareness & 0.55 & 0.82 \\
\hline Scientific Process & 0.53 & - \\
\hline Facilitation & 0.52 & 0.81 \\
\hline Sharing Ideas & 0.49 & \\
\hline
\end{tabular}

Table 3 revealed that there were eight factors as the result of factor analysis. However, using LISREL ${ }^{\mathrm{TM}}$ analysis to confirm those eight factors, it was found that only five factors of students' perceptions related to the effective use of PBL.

\section{Descriptive Summary Of Students' Perceptions}

The first factor included the following: Motivation to Learn, which refers to the learners' ability to think and use materials provided by the instructors imaginatively; and Thinking Skills, learners' capacity for vision and 
lateral thinking as well as their use of reason in their thinking and actions, creative thinking, and use of new concepts/principles to solve problems. Factor 3 related to the Scientific Process and the learners' ability to state a problem, set up a hypothesis and choose the best way to solve problems. For factor 4, students identified the importance of Sharing Ideas, refers to an interaction of students with peers. Factor 5 related to Goal-Setting. Learners need to be able to set the directions and/or scope for planning a project, set goals and steps to carry the project through to the desired outcomes, and anticipate outcomes of a project.

\section{Comparison of perspectives}

Table 4 shows that there were significant differences among instructors and students on their perceptions of the importance of Sharing Ideas and Thinking Skills in PBL, $t=-3.58, p<.01$ and $t=-3.01, p<.01$, respectively. Students were more likely than instructors to affirm Sharing Ideas and Thinking Skills as important.

Table 4: Comparison Of The Factors Perceived As Important From LISREL $^{\mathrm{TM}}$ Analysis Using T Test Between Instructors And Students

\begin{tabular}{|c|c|c|c|c|c|c|c|}
\hline Factor & Status & $\mathbf{n}$ & M & SD & $\begin{array}{c}\text { Mean } \\
\text { Difference }\end{array}$ & $\mathbf{t}$ & $\mathbf{p}$ \\
\hline \multirow[t]{2}{*}{ Sharing Ideas } & Instructors & 180 & 5.33 & 0.96 & \multirow{2}{*}{-0.36} & \multirow{2}{*}{$-3.58^{* * *}$} & \multirow{2}{*}{0.001} \\
\hline & Students & 116 & 5.69 & 0.74 & & & \\
\hline \multirow[t]{2}{*}{ Motivation to Learn } & Instructors & 180 & 5.53 & 1.03 & \multirow{2}{*}{-0.15} & \multirow{2}{*}{-1.41} & \multirow{2}{*}{0.16} \\
\hline & Students & 116 & 5.68 & 0.76 & & & \\
\hline \multirow[t]{2}{*}{ Scientific Process } & Instructors & 180 & 5.27 & 0.96 & \multirow{2}{*}{-0.17} & \multirow{2}{*}{-1.53} & \multirow{2}{*}{0.13} \\
\hline & Students & 116 & 5.44 & 0.88 & & & \\
\hline \multirow[t]{2}{*}{ Thinking Skills } & Instructors & 180 & 5.29 & 0.97 & \multirow{2}{*}{-0.33} & \multirow{2}{*}{$-3.01^{* *}$} & \multirow{2}{*}{0.001} \\
\hline & Students & 116 & 5.62 & 0.83 & & & \\
\hline
\end{tabular}

P $P<0.01$.

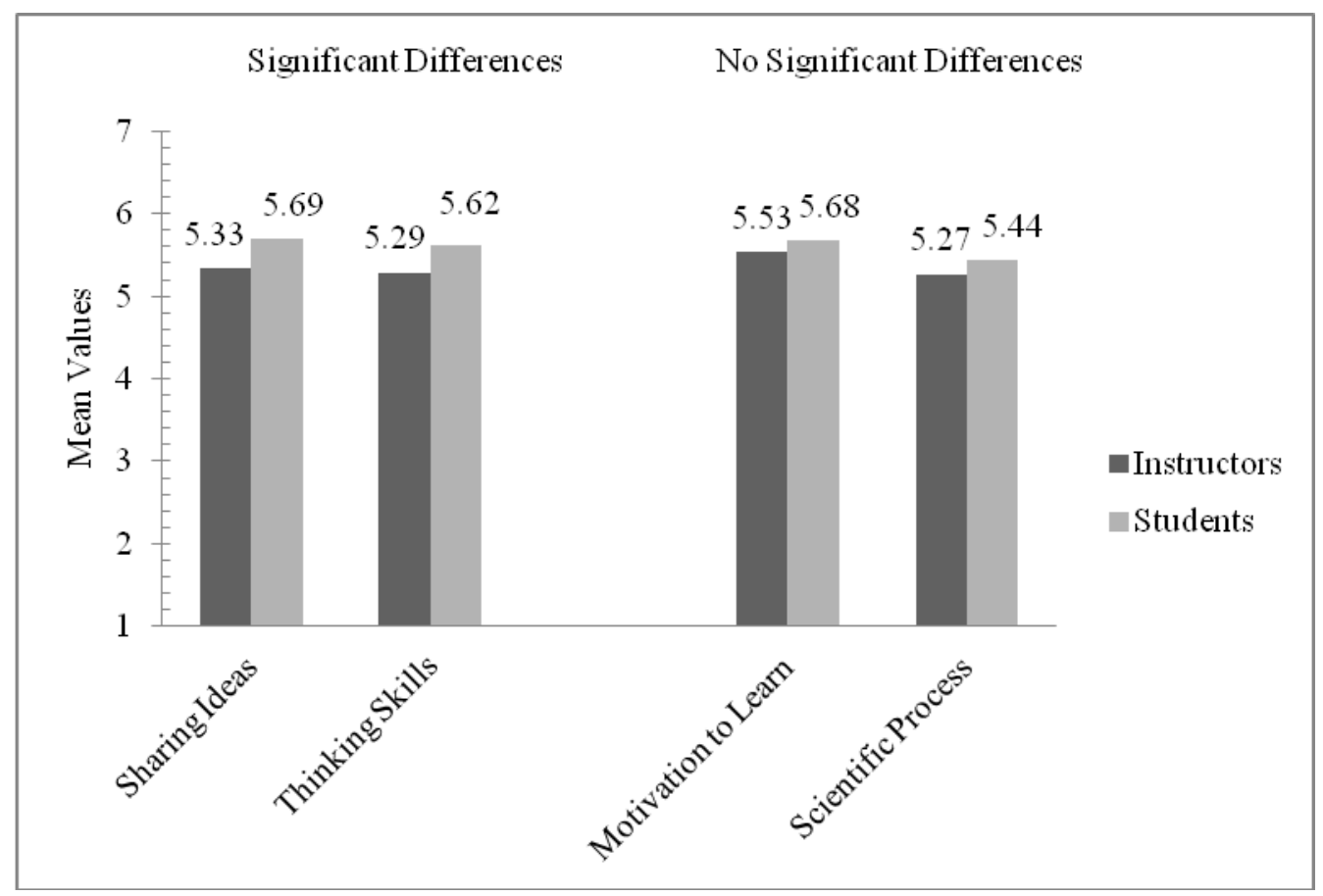

Figure 3: A Chart Of The Mean Values Of Factors Perceived As Important By Instructors And Students 
Figure 3 presents a chart indicating that both instructors and students perceived Motivation to Learn and an emphasis on Scientific Process as important factors. Compared to instructors, students were significantly more likely to value Sharing Ideas and Thinking Skills. In PBL classrooms, instructors' perceptions of students' learning achievement through PBL may focus less on Thinking Skills and Sharing Ideas than on Motivation to Learn or Scientific Process. It was found that both instructors and students perceived that Motivation to Learn and an emphasis on Scientific Processes are important components of PBL environment. Compared to instructors, students placed a significantly greater emphasis on Sharing Ideas and Thinking Skills, although partial eta squared values indicated that the effect sizes were quite small. These findings are important in light of persuasive evidence that students' perceptions and preferences with respect to their classroom learning environment account for significant variance in cognitive and affective outcomes (for example, intrinsic motivation, self-concept, liking for particular subjects and students' intention to drop out). See, for example, Tapola and Niemivirta, 2008.

\section{DISCUSSION}

The results obtained in this study, where two factors present significant differences and two factors indicate no significant differences, may be interpreted in the light of students' and instructors' experiences and roles in the PBL classroom. The literature on PBL (Doppelt, 2005; Frank \& Barzilai, 2006; Knoll, 1997; Mitchell et al., 2009; Polman, 2000; Teoh, 2003; Tongsakul \& Jitgarun, 2006a; Tongsakul \& Jitgarun, 2006b) highlights some important differences between instructors' and students' roles and experiences in PBL classrooms. These differences have been condensed and presented in Table 5 .

Table 5: Comparison Of The Roles Of Students And Instructors In PBL Classrooms, As Related In The Literature And In Our Research Findings

\begin{tabular}{|l|l|l|l|}
\hline \multicolumn{1}{|c|}{ Learning Activities } & \multicolumn{1}{|c|}{ The Roles of } & \multicolumn{1}{|c|}{ PBL Literature } & \multicolumn{1}{|c|}{ Our Research Findings } \\
\hline \multirow{3}{*}{ Teamwork } & Students & $\begin{array}{l}\text { Discover answers through inquiry by working with } \\
\text { peers and brainstorming. Then, the team is required to } \\
\text { make a decision or solve a problem. }\end{array}$ & $\begin{array}{l}\text { Develop thinking skills, } \\
\text { use scientific processes, } \\
\text { and develop intelligent } \\
\text { awareness }\end{array}$ \\
\cline { 2 - 4 } & Teachers & $\begin{array}{l}\text { Develop an atmosphere of shared responsibility or act } \\
\text { as a mentor or tutor to the group. }\end{array}$ & Facilitate learning \\
\hline \multirow{5}{*}{ Share Learning } & Students & $\begin{array}{l}\text { Share learning experiences in order to accomplish } \\
\text { specific goals. }\end{array}$ & Share ideas \\
\cline { 2 - 5 } Interdependence & Teachers & $\begin{array}{l}\text { Ensure students' projects remain focused and have a } \\
\text { deep understanding of the concepts being investigated. }\end{array}$ & Plan experiences, set goals \\
\cline { 2 - 5 } & Students & Work interdependently on well-defined tasks. & $\begin{array}{l}\text { Collaborate and assist, } \\
\text { advise and guide }\end{array}$ \\
\cline { 2 - 5 } & Teachers & $\begin{array}{l}\text { Provide immediate feedback on student work and } \\
\text { discussion, and evaluate students. }\end{array}$ & Share ideas \\
\hline
\end{tabular}

Table 5 is derived from a literature review (Mcinerney \& Fink, 2003; Nam 2003; Rumpagaporn \& Darmawan, 2007; Sweeney, 2000; Yoon \& Choi, 2009) and clarifies the different experiences that are reflected in the present findings. It is interesting to note that these differences can also be seen in other 'alternative' instructional strategies such as collaborative learning (Harding-Smith, 1993; Kollar et al., 2006; Smith \& MacGrogor, 1992); cooperative learning (Johnson \& Johnson, 1989; Millis \& Cottell, 1998; Slavin, 1990); team-based learning (Michaelsen, 2004); game-based learning (Ricci, Salas \& Cannon-Bowers, 1996; Garris, Ahlers \& Driskell, 2002). PBL and the alternative instructional strategies differ markedly from traditional instruction since most students may become more committed to learning and develop a shared vision.

In the learning orientation approach, students move beyond the traditional cycle that emphasizes passive learning, where the instructor lectures and students memorize the material for examinations. In the team-based active learning process, the instructor is the facilitator and students work on actual problems to develop critical or higher order thinking (Celuch \& Slama, 1998, 2000, 2002; Hernandez, 2002). This view is congruent with Kolb (1984) who explains that, in student-centered learning, greater emphasis is placed on students' exploration of the 
material. Therefore, students engage in higher-order thinking (such as, analysis, synthesis, and evaluation) as a result of the interplay of affect, perception and cognition.

In the case of PBL, students are the main people responsible for managing learning through group work and for working collaboratively with other students. When students interact with other members of their group, they will envision how others learn and, thus, develop a better sense of how they learn (Georghiades, 2000; Vosniadou et al., 2001). More specifically, the PBL learning process allows learners to study, search, set goals, plan, practice, and/or experiment according to their interest, preferences, and capability. PBL in groups and with individuals relies on thinking processes, integrating knowledge, and using a scientific method in each step. During PBL, learners think, do, solve problems, and share knowledge together (Jitgarun et al., 2006). Outcomes may include decision making and team-based strategic thinking, management skills (for example, planning, communications, selfreliance) (de Freitas, 2006).

In the results of the present research, a significant difference was found between instructors' and students' perceptions on two factors: Sharing Ideas and Thinking Skills to empower PBL. Whereas students are more likely to engage in groups so that they can share ideas and work collaboratively with their peers on their project, instructors, on the other hand, believe their role is to engage in other activities in the classroom, such as developing an atmosphere of shared responsibility or acting as a mentor to the group. They do not perceive that it is their classroom role to engage in sharing ideas, but to provide immediate feedback on student work and discussion, or to evaluate students. Therefore, although the literature suggests that these two factors (Sharing Ideas and Thinking Skills) are embraced in PBL, the results of the present research suggest a divergence in the perceptions of students and instructors.

\section{CONCLUSIONS AND LIMITATIONS}

As we noted earlier (Chabbott, 2001; Office of Commercial Services, 2002), PBL in Thailand can potentially help the country implement reform and move away from teacher-centered learning and memorization to allow students to think and analyze independently, and to learn from experience and practice. Nevertheless, students need to be motivated to learn, and they need to be able to set goals, think independently, be aware, share ideas, and engage in scientific processes. For instructors in Thailand, creating the appropriate classroom conditions/atmosphere necessary for these activities presents a challenge. As Barron et al. (1998) noted regarding implementation of PBL in the U.S.A., PBL will involve overcoming "a major hurdle" and will require "changes in curriculum, instruction, and assessment practices; changes that are often foreign to students as well as the teachers" (p. 306). Barron et al. suggest that new models of professional development will be required. If instructors in Thailand are to implement PBL, there is a need for training so they will become more aware of the role and importance of sharing and thinking. In addition, they will need to be provided with strategies for motivating students and engaging them in setting-goals, becoming aware, and engaging in scientific processes.

The present study of instructors' and students' perceptions of factors that empower students in PBL focused only on instructors at vocational education institutes in Thailand and students in a department in a Faculty of Industrial Education and Technology in Thailand. The scope for generalization is therefore limited. The study is also limited to the use of questionnaire data only. In addition, the questionnaire used pre-determined variables from which students could choose. If the participants had been allowed to choose their own variables, the results may have been very different.

Since it was beyond the scope of this present study to explore the possible explanation for their perceptions, only partial and tentative answers have been provided to the question of why instructors and students chose certain factors and not others. Therefore, there is a need for further research. Follow-up interviews with both instructors and students may provide insight into why they differed and why they selected certain factors over others. Follow-up interviews may also provide insight into why both instructors and students did not consider certain factors to be more important than others, especially Facilitation, Goal-Setting, Planning, Intelligent Awareness, and Learning by Doing. 


\section{ACKNOWLEDGEMENTS}

The researchers would like to express very special thanks for the advice of Professor Elizabeth Murphy, Faculty of Education, Memorial University, Newfoundland and Labrador, Canada as well as David Crookall, Université de Nice Sophia Antipolis, France and Kenneth Dun, formerly of Assumption University of Thailand for proofreading and editing this article.

\section{AUTHOR INFORMATION}

Anuvat Tongsakul is a teacher in the Department of Electrical Power at Phang Nga Technical College, Phang Nga, Thailand, and a doctoral candidate in the Learning Innovation in Technology Program at King Monkut's University of Technology Thonburi, Thailand. E-mail: anuvattongsakul@ hotmail.com

Kalayanee Jitgarun is an Associate Professor in the Department of Electrical Technology Education at King Mongkut's University of Technology Thonburi, Thailand. She has twenty-five years' experience in teaching and conducting research on curriculum and instruction and has authored various publications, most recently on quality assurance in engineering education and vocational education. E-mail: kalayanee.jit@kmutt.ac.th

Weerachai Chaokumnerd is a member of the Amateur Radio Committee, Office of the National Broadcasting and Telecommunications Commission, Bangkok, Thailand. He has authored papers in the field of Engineering. Dr. Weerachai Chaokumnerd also holds the position of Captain in the Royal Thai Air Force. His main research interests are telecommunication management and electrical and electronic systems. E-mail: weerachai.chd@ hotmail.com

\section{REFERENCES}

1. Barron, B.J.S., D.L. Schwartz, N.J. Vye, A. Moore, T. Petrosino, L. Zech, and J.D. Bransford. 1998. Doing with understanding: Lessons from research on problem- and project-based learning. Journal of the Learning Sciences 7, no. 3/4: 271-311.

2. Blumenfeld, P.C., E. Soloway, R. W. Marx, J.S.Krajcik, M.Guzdial, and A.Palincsar. 1991. Motivating project-based learning: Sustaining the doing, supporting the learning. Educational Psychologist 26, no. 3/4: 369-398.

3. Bureau of Monitoring and Evaluation of Vocational Education. (2009). A Summary Report on the Major Outputs by the Office of Vocational Education Commission, Bangkok, Thailand.

4. Chabbott, C. 2001. UNICEF'S Child-Friendly Schools in Thailand: A Case Study. http://www.unicef.org/girlseducation/files/CFS_Case_Study_-_Thailand.pdf (accessed June 11, 2010).

5. Celuch, K., and M. Slama. 1998. Critical thinking as an integrative theme for teaching lifelong learning skills in Marketing. Marketing Education Review 8, no. 3: 1-12.

6. Celuch, K., and M. Slama. 2000. Student perceptions of a Marketing course taught with the Critical Thinking Approach. Marketing Education Review 10, no. 1: 57-64.

7. Celuch, K., and M. Slama. 2002. Promoting critical thinking and life-long learning: An experiment with the Theory of Planned Behavior. Marketing Education Review 12, no. 2: 13-22.

8. de Freitas, S. 2006. Learning in Immersive Worlds: A Review of Game Based Learning. http://www.jisc.ac.uk/media/documents/programmes/elearninginnovation/gamingreport v3.pdf (accessed June 11, 2010).

9. Doppelt, Y. 2005. Assessment of project-based learning in a Mechatronics context. Journal of Technology Education 16, no. 2: 7-24.

10. Education for all. 2000. Thailand country report. World Education Forum. http://www.unesco.org/education/wef/countryreports/thailand/rapport 2 2.html (accessed June 11, 2010).

11. Fallik, O., B.S.Eylon, and S. Rosenfeld. 2008. Motivating teachers to enact free-choice Project-Based Learning in Science and Technology (PBLSAT): Effects of a professional development model. Journal of Science Teacher Education 19, no. 6: 565-591.

12. Frank, M., and A.Barzilai. 2006. Project-Based Technology: Instructional strategy for developing technological literacy. Journal of Technology Education 18, no. 1: 39-53. 
13. Frank, M., I. Lavy, and D. Elata. 2003. Implementing the Project-Based Learning approach in an academic Engineering course. International Journal of Technology and Design Education 13: 273-288.

14. Garris, R., R. Ahlers, and J.E. Driskell. 2002. Games, motivation and learning: A research and practice model. Simulation \& Gaming 33, no. 4: 441-467.

15. George, D., and P. Mallery. 2003. SPSS for windows step by step: A simple guide and reference 11.0 update. 4th ed. Boston, MA: Allyn \& Bacon.

16. Georghiades, P. 2000. Beyond conceptual change learning in science education: focusing on transfer, durability and metacognition. Educational Research 42, no. 2: 119-139.

17. Gliem, J.A., and R.R. Gliem. 2003. Calculating, interpreting, and reporting Cronbach's alpha reliability coefficient for Likert-type scales. In Proceedings of the Midwest Research to Practice Conference in Adult, Continuing, and Community Education, 82-88. Columbus, $\mathrm{OH}$.

18. Gorsuch, R.L. 1983. Factor analysis. 2nd ed. Hillsdale, NJ: Lawrence Erlbaum Associates.

19. Harding-Smith, T. 1993. Learning together: An introduction to collaborative learning. New York, NY: Harper Collins College Publishers.

20. Harman, H.H. 1976. Modern factor analysis. 3rd ed. Chicago, IL: University of Chicago Press.

21. Hernandez, S.A. 2002. Team learning in a marketing principles course: Cooperative structures that facilitate active learning and higher level thinking. Journal of Marketing Education, 24, no. 1: 73-86.

22. Jitgarun, K., and A.Tongsakul. 2009. Virtual-based training and critical thinking in Higher-level education. Cypriot Journal of Educational Sciences 4: 2-14.

23. Jitgarun, K., A. Chaisawadi, P. Kumhom, and S. Ploisawaschai. (n.d.). Enhancing the quality of student feedback in engineering programmes in Thailand. Student Feedback in Engineering Education, Manuscript submitted for publication (copy on file with author).

24. Jitgarun, K., A.Tongsakul, and S. Meejaleurn. 2008. Virtual-based training and creative thinking in Higherlevel education. In Proceedings of EDU-COM 2008 International Conference, 268-276. Khon Kaen, Thailand.

25. Jitgarun, K., S. Thaweesin, C. Vithayaporn, C. Chunkul, and A. Tongsakul. 2006. A study of project-based learning tools: A case study of Darunsikkhalai School. In Proceedings of the Asia-Pacific Educational Research Association International Conference 2006, 1-17. Hong Kong.

26. Johnson, D.W., and R. T. Johnson. 1989. Cooperation and competition: Theory and research. Edina, MN: Interaction Book Company.

27. Joreskog, K. G., and D. Sorbom. 1996. LISREL 8: User's Reference Guide. Chicago: Scientific Software International, Inc.

28. Kaewdang, R. 1998. Thailand education reform. Bangkok, Thailand: Matichon.

29. Kilpatrick, W.H. 1918. The project method. Teachers College Record 19: 319-335.

30. Knoll, M. 1997. The project method: Its vocational education origin and international development. Journal of Industrial Teacher Education 34, no. 3: 59-80.

31. Kolb, D.A. 1984. Experiential learning: Experience as the source of learning and development. Englewood Cliffs, NJ: Prentice-Hall.

32. Kollar, I., F. Fischer, and F.W. Hesse. 2006. Collaboration scripts - a conceptual analysis. Educational Psychology Review 18, no. 2: 159-185.

33. Krajcik, J., C. Czerniak, and C. Berger. 1999. Teaching Science: A Project-Based Approach. New York, NY: McGraw-Hill College.

34. Markham, T., J. Larmer, and J. Ravitz. 2003. Project based learning handbook. 2nd ed. Novato, CA: Wilsted \& Taylor Publishing Services.

35. Mcinerney, M.J., and L. D. Fink. 2003. Team-Based Learning enhances long-term retention and critical thinking in an undergraduate Microbial Physiology course. Journal of Microbiology \& Biology Education 4: 3-12.

36. Michaelsen, L.K. 2004. Getting started with team-based learning. In Team-Based Learning: A transformative use of small groups. ed. L.K. Michaelsen, A.B. Knight, and L.D. Fink. 27-50. Westport, CT: Praeger Publishers.

37. Millis, B.J., and P.G. Cottell, Jr. 1998. Cooperative learning for Higher Education faculty. Phoenix, AZ: The Oryx Press.

38. Mulkam, S., and O. Mulkam. 2002. Instruction methods: To develop morals, values and learning by oneself. Bangkok, Thailand: Phabpim. 
39. Mitchell, S., T.S. Foulger, K. Wetzel, and C. Rathkey. 2009. The negotiated project approach: ProjectBased Learning without leaving the standards behind. Early Childhood Education Journal 36: 339-346.

40. Nam, C. S. 2003. A theory-based integrated design process for development and evaluation of Web-based supplemental learning environments. Ph diss, Virginia Polytechnic Institute and State University. http://scholar.lib.vt.edu/theses/available/etd-12182003-230607/unrestricted/csnamdiss.pdf (accessed June 13, 2010).

41. Nunnally, J. 1988. Psychometric theory. NewYork, NY: McGraw-Hill.

42. Office of Commercial Services. 2002. Teacher Development for Quality Learning. The Thailand Education Reform Project. http://www.edthai.com/publication/0005/fulltext.pdf (accessed June 11, 2010).

43. Office of the National Education Commission. 2003. National education act B.E. 2542 (A.D. 1999) and Amendments (Second National Education Act B.E.2545 (A.D. 2002)). Bangkok, Thailand: Office of the National Education Commission.

44. Office of the National Primary Education Commission. 2002. Project-Based Learning. Bangkok, Thailand.

45. Office of the Vocational Education Commission. 2003. 2003 Curriculum for Diploma of Vocational Education. http://bsq.vec.go.th/course/Eng/diploma eng.pdf (accessed February 7, 2011).

46. Orevi, N., and R. Dannon. 1999. Learning ecology with educational technologies. Paper presented at the International Workshop on Science Teachers Education Toward the New Millennium, Haifa, Israel.

47. Pannabecker, J.R. 1995. For a history of technology education: Contexts, systems, and narratives. Journal of Technology Education 7, no. 1: 43-56.

48. Petcharak, S. 2001. Research Report on Constructionism in Thailand. Bangkok, Thailand: Office of the National Education Commission.

49. Poell, R., F. Van der Krogt and J. Warmerdam. 1998. Project-based learning in professional organizations. Adult Education Quarterly, 49(1), 28-42.

50. Polman, J.L. 2000. Designing project-based science: Connecting learners through guided inquiry. New York, NY: Teachers College Press.

51. Ricci, K., E. Salas, and J.A. Cannon-Bowers. 1996. Do computer-based games facilitate knowledge acquisition and retention? Military Psychology 8, no. 4: 295-307.

52. Rumpagaporn, M.W., and I.G.N. Darmawan. 2007. Students' critical thinking skills in a Thai ICT schools pilot project. International Education Journal 8, no. 2: 125-133.

53. Slavin, R.E. 1990. Cooperative learning: Theory, research and practice. Englewood Cliffs, NJ: Prentice Hall.

54. Smith, B., and J. MacGregor. 1992. What is collaborative learning? http://learningcommons.evergreen.edu/pdf/collab.pdf (accessed June 11, 2010).

55. Sweeney, K.J. 2000. Problem Based Learning in Histology: Are Understanding and Motivation Enhanced? http://www.middlesex.mass.edu/Carnegie/PDFs/sweeney.pdf (accessed June 11, 2010).

56. Tapola, A., and M. Niemivirta. 2008. The role of achievement goal orientations in students' perceptions of and preferences for classroom environment. British Journal of Educational Psychology, 78, 291-312.

57. Teoh, K.S. 2003. Project-Based Learning in Engineering education: An approach used by Monash University Malaysia. In Proceedings of 2003 International Conference on Engineering Education, 14.Valencia, Spain.

58. Thomas, J. 2000. A review of research on project-based learning. San Rafael, CA: Autodesk Foundation.

59. Tongsakul, A., and K. Jitgarun. 2006a. An analysis of factors affecting project-based learning. In Proceedings of the 4th International Conference on Developing Real-Life Learning Experiences: Education Reform through Performance-Based Learning, 246-254. Bangkok, Thailand.

60. Tongsakul, A., and K. Jitgarun. 2006b. Empowering students' learning achievement through project-based learning as perceived by electrical instructors and students. In Proceedings of the EDU-COM 2006 Engagement and Empowerment: New Opportunities for Growth in Higher Education, 509-518. Nong Khai, Thailand.

61. Turner, R.C., and L. Carlson. 2003. Indexes of item-objective congruence for multidimensional items. International Journal of Testing 3, no. 2: 163-171.

62. Vogt, W.P. 2007. Quantitative research methods for professionals. Boston, MA: Pearson Education. 
63. Vesterinen, P.,_and J. Lasonen. 2000. Work-based learning in vocational higher education programmes: A Finnish case of project-based learning. Paper presented at the Annual Conference of the Association for Career and Technical Education/International Vocational Education and Training Association (74th, San Diego, CA.).

64. Vosniadou, S., C. Ioannides, A. Dimitrakopoulou, and E. Papademetriou. 2001. Designing learning environments to promote conceptual change in science. Learning and Instruction 11, no. 4: 381-419.

65. Warr, P., J. Cook, and T. Wall. 1979. Scales for the measurement of some work attitudes and aspects of psychological well-being. Journal of Occupational Psychology 52: 129-148.

66. Wen, L.M.L., C.-C. Tsai, H.-M. Lin, and S.-C. Chuang. 2004. Cognitive-metacognitive and contenttechnical aspects of constructivist Internet-based learning environments: A LISREL analysis. Computers \& Education 43: 237-248.

67. Yaghmaie, F. 2003. Content validity and its estimation. Journal of Medical Education 3, no. 1: 25-27.

68. Yoon, G. 2001. A study of project-based instructional systems design (p-isd) model development for engineering practice education. In Proceedings of the International Conference on Engineering Education. Oslo, Norway: INEE. http://www.ineer.org/Events/ICEE2001/Proceedings/papers/444.pdf (accessed June 13, 2010).

69. Yoon, S. W., and W.K. Choi. 2009. A study on student cognition for multi-dimensional appraisal of introductory Engineering design course. In Proceedings of the International Conference on Engineering Education and Research. Seoul, Korea. http://www.ineer.org/Events/ICEEiCEER2009/full_papers/full_paper_136.pdf (accessed June 13, 2010). 


\section{NOTES}

